\title{
BUDAPEST IPARI TERÜLETEI AZ UTÓBBI ÉVTIZEDBEN
}

\author{
(Industrial Areas of Budapest in the Last Decade)
}

\section{KISS ÉVA}

Kulcsszavak:

ipar dezindusztrializáció funkcióváltás Budapest

A föváros tradicionális ipari területein az utóbbi évtizedben is folytatódtak azok a folyamatok (de- és reindusztrializáció, rehabilitáció, ipari terïletek csökkenése, finkcióváltás), amelyek az 1990-es évtizedben voltak jellemzöek, de már sok vonatkozásban különböznek is azoktól. Tulajdonképpen ezeket mutatja be ez a tanulmány egy újabb felmérésre alapozva.

\section{Bevezetés}

Közel egy évtized telt el azóta, hogy az 1990-es évek végén megjelent ezen folyóirat hasábjain az a tanulmány, amely a budapesti ipari területeken 1989 óta lezajlott térszerkezeti és funkcionális változásokat foglalta össze. S, hogy mi történt a föváros ipari területein az elmúlt évtizedben, a 20. század végétỏl napjainkig, azt foglaljuk össze elsődlegesen ebben a cikkben. A teljességre törekvés és az összevethetôség érdekében azonban meg kell említeni az 1989 és 1998 közötti időszak néhảny fontosabb jellemzöjét is. Nem hagyhatók figyelmen kívül a korábban leírt tapasztalatok azért sem, mert bizonyos fokig arra is választ keresünk, hogy az 1990-es évtizedbeli folyamatok hogyan folytatódtak, milyen mértékben és miért változtak az új évezred elején. Az ismétlések elkerülése végett eltekintünk viszont azoknak a fejezetrészeknek az ismertetésétöl, amelyek a kutatástörténeti előzményeket, illetve a budapesti ipar és ipari területek történeti fejlődését mutatják be (Kiss 1999). Az előbbiekhez kapcsolódóan mindössze egy táblázatos kiegészítést érdemes tenni, ami a nyugati és az Európa keleti felének nagyvárosaiban lezajlott ipari átalakulás okait és következményeit, a hasonlóságokat és a különbségeket foglalja össze (1. táblázat).

Ezen munka alapjául az a 2006-ban végzett felmérés ${ }^{1}$ szolgált, amely a budapesti ipari területek nagyságában és funkciójában bekövetkezett változások feltárására irányult. Az ipari területek egyenkénti, tömbönkénti feltérképezése nagyon részletes információkat szolgáltatott a hasznosításukról. A vizsgálat a City kivételével, a fóváros valamennyi kerületére, s az ott található összes ipari területre kiterjedt. Bázis térképként a kerületi térképek szolgáltak, amelyek különböző (1:7000 és 1:13 000 közötti) méretarányban készültek, és a 2000-es évek elején (2002-2004 között) jelentek meg. Ezeken a térképeken jelölve voltak az iparinak minósített területek, melyekhez viszonyítva készült el a 2006. évre vonatkozó funkcionális hasznosítás, azaz, hogy ténylegesen milyen tevékenységek is folytak akkor az egyes, iparinak 
jelölt területeken. Ebből az ún. alaptérképből „,kiszürtük” azokat a területeket, amelyeken valóban ipari tevékenység folyt, és külön térképen ábrázoltuk.

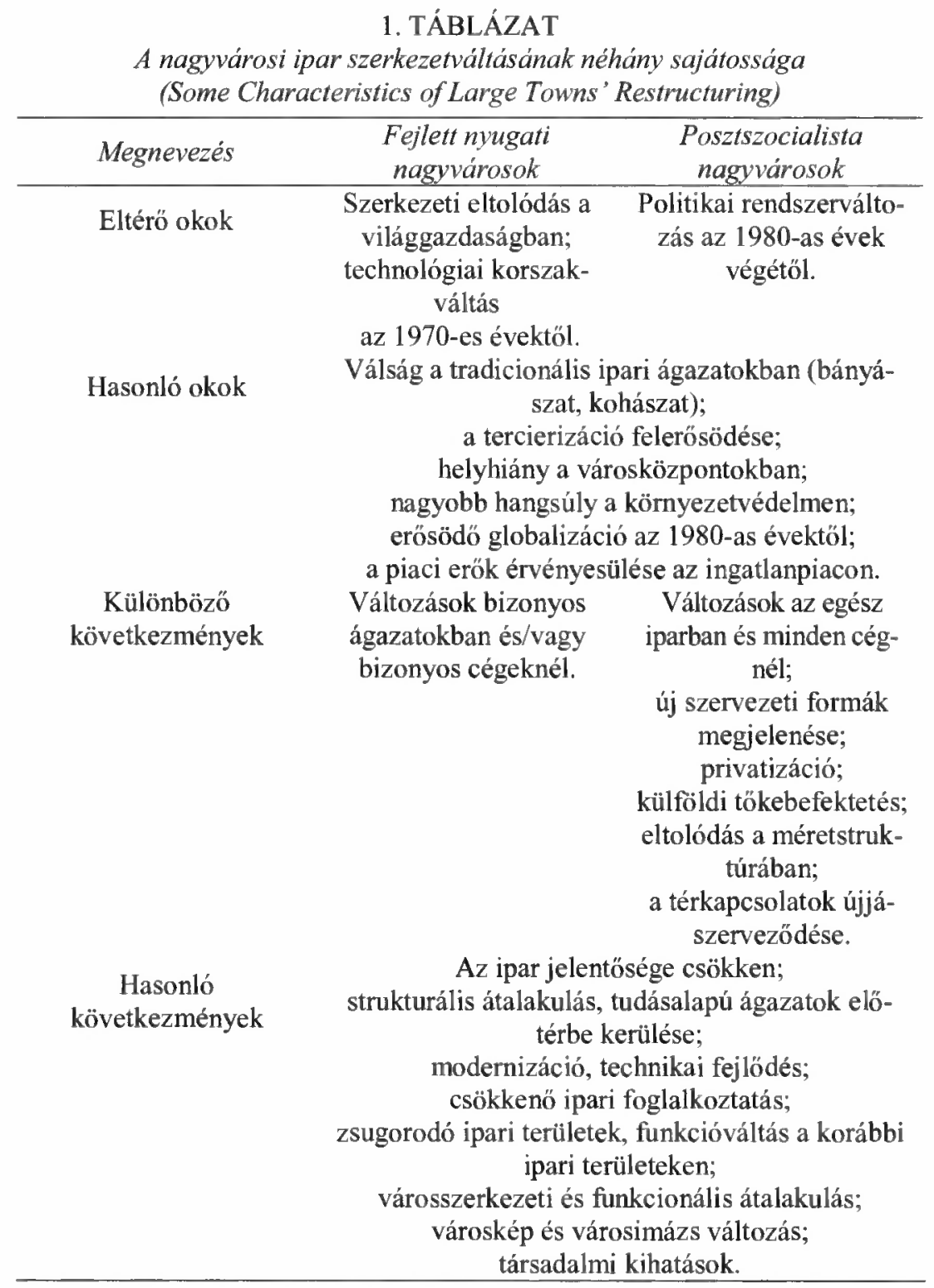

Forrás: Kiss (2002) alapján saját szerkesztés.

A kutatás következő fázisában az így kapott térképet összehasonlítottuk az 1998. évivel, hogy feltárjuk, az akkor ipariként jelölt területekböl mennyi maradt meg 2006-ra is ipari területnek. Az eredmény a hipotézisünket igazolta. Nevezetesen, hogy az ipari 
területek kiterjedése tovább mérséklődött az elmúlt évtizedben. Így van ez még akkor is, ha a felmérés során felmerült esetleges pontatlansági tényezőket is figyelembe vesszük, amelyek részben objektív, részben szubjektiv tényezőből fakadtak (pl. felmérést végzők szubjektivitása, becslések pontosságának vitathatósága stb.).

A nagyvárosok ipari területeinek pontos meghatározása mindig sok módszertani problémát vetett fel nemcsak a múltban, hanem az elmúlt évtizedben végzett felmérések alkalmával is (Prinz 1964). Ezek egyfelöl az 1989 után megszaporodott új cégeknek tulajdonithatók, amelyeket részben az egykori szocialista nagyválialatok területén hoztak létre. Gyakran elöfordult ugyanis, hogy egy-egy régi ipari területen vagy az ottani épületeken több tucat cég osztozott, miáltal a tulajdonviszonyok szinte „kibogozhatatlanok”, követhetetlenek voltak. Másfelöl szintén megnehezítette a felmérést az, hogy a cégek egy részét tevékenységük jellege alapján nem lehetett pontosan besorolni, mivel az ipari tevékenységen kívül nem ipari (pl. javító, kereskedelmi, logisztikai, egyéb szolgáltatási) tevékenységet is folytattak valamilyen mértékben. Arról nem is szólva, hogy az ipari területen jó néhány olyan cég is volt, amelyek nem ipari tevékenységet végeztek. Ezek miatt sok esetben csak becslésekre támaszkodhatunk az ipari területek nagyságát és funkcionális hasznosítását illetően. A térképi megjelenités több cég esetében azért okozott gondot, mert túl kicsik voltak ahhoz, hogy kisméretủ térképen ábrázoljuk. Tekintettel az előbbiekre a következő elvet követtük a felmérés folyamán. Minden esetben a cégek elsődleges tevékenységét vettük alapul, és az ipari és nem ipari tevékenységek által elfoglalt területek nagyságát becsléssel határoztuk meg. Ez természetesen azt is jelenti, hogy a megfigyelésen és szubjektív megítélésen alapuló eredmények nem teljesen objektívek, de arra mindenképp alkalmasak, hogy a domináns tendenciákat jelezzék.

A nagyon időigényes terepmunka során alkalmazott módszerek (megfigyelés, munkatérképek és fotók készitése) mellett a CompLex Céghírek cégadatbázisára támaszkodtunk és interjúkat is készítettünk. Legutóbb 2006 tavaszán kerestük fel a fövárosi föépítészi hivatalt és néhány olyan kerületi önkormányzati hivatalt, amelyek (1989 után) tetemes kiterjedésủ ipari területekkel rendelkeztek, hogy a foépítészekkel készített interjúk révén az ipari területekkel kapcsolatos legújabb álláspontokról és a jövőjükre vonatkozó elképzelésekről tájékozódjunk.

A tanulmány két fö részből áll a bevezetést és az összegzést nem számítva. Elöször a fơvárosi ipari területeken megfigyelhető föbb tendenciákat, sajátosságokat foglaljuk össze, majd pedig a feleslegessé vált ipari területek lehetséges hasznositási módjait tekintjük át.

\section{Föbb tendenciák az ipari területeken}

Budapest fejlődése során, ahogy azt már Mendöl is leírta, egy sajátos gyủrűssugaras városszerkezet jött létre, amely leginkább Burgess modelljéhez hasonlít (Mendöl 1963; Csanádi-Ladányi 1992). A négy gyürü kialakulásában különböző természeti és társadalmi, gazdasági stb. tényezők játszottak szerepet. Szabályos 
Tér és Társadalom 23. évf. 2009/2. 69-85. p.

kifejlődésüket egyrészt a budai oldalon a domborzati viszonyok akadályozták, másrészt a városból kivezetö fontosabb föutak törik meg. Mindegyik övezetnek megvolt (s részben ma is megvan) a maga speciális funkciója, melyek közül a negyedik, a második lakóhelyi övezet kivételével az elsö három (City, első lakóhelyi övezet, második munkahelyi övezet) jelentős változások színtere lett a rendszerváltozás után, de más-más aspektusból (Berényi 1994). A budapesti iparban lezajlott változások, amelyeket nagyon sok tényező indukált, leginkább a második munkahelyi övezet vagy másképp az átmeneti zóna részét képezö ipari területeket érintették. A bekövetkezett változások tulajdonképpen az iparban végbement nagyhorderejü (szervezeti, szerkezeti, tulajdoni stb.) változások térbeli vetületeként is értelmezhetők, azaz a funkcionális szerkezetváltás területi konzekvenciájaként (Coffey-Bailly 1996). Az iparban végbement változások különösen az 1990-es évtizedben játszottak markáns szerepet az ipari területeken lezajlott folyamatokban. Majd azt követően egyre jobban előtérbe kerülttek azok a tényezök (pl. piaci viszonyok, tudatos városfejlesztési politika), amelyek már nem az iparhoz és az ipari tevékenységhez kapcsolhatók. S ma már nem annyira az ipar, hanem elsősorban más faktorok indukálják az ipari területeken megfigyelhető változásokat Budapesten is. A hajtóerők fontossági sorrendjében tehát releváns változás ment végbe az elmúlt csaknem két évtizedben.

A kelet-közép-európai fövárosok közül Budapest örökölte a legnagyobb kiterjedésủ ipari területeket. Ez egyaránt lehet nagyon kedvezötlen és nagyon kedvezö adottság. Az elöbbi azért, mert a más városokkal vívott, egyre éleződö versenyben hátrányt okozhat az, hogy a kiterjedt, sokszor szennyezett ipari területek felszámolása sokba kerül. A felmerülö költségek ugyanis súlyos teherként nehezednek a városra, ami inkább elriaszt(hat)ja a befektetöket. Másfelöl viszont ezek az ipari területek a föváros „aranytartalékainak" is tekinthetök. Következésképp rendkívül fontosak és hasznosak lehetnek a város számára, mert igen kevés a szabad, beépítetlen terület a belső városrészekben, szemben a más nagyvárosokban (pl. Varsóban) tapasztaltakkal (Kiss 2007).

A föváros ipari területeit többféle megnevezéssel (barnazóna, rozsdaövezet stb.) is szokták illetni, amelyek tartalmukban is különböznek többé-kevésbé. A barnaövezet - szükebb értelemben - csak a kifejezetten ipari területeket jelenti, de tágabb értelmezésben az egész átmeneti zónát jelöli, ahol nem csak ipari, hanem más, nagy területigényü közlekedési és egyéb létesítmények is megtalálhatók. Éppen ezért funkcionális aspektusból vegyes funkciójú övezetként szokták említeni az átmeneti zónát, ami az ipari és nem ipari funkciók keveredésére utal. Az ipari területeket szintén gyakran illetik a "rozsdaövezet” megnevezéssel is. Ez a név rendszerint azokat az ipari területeket jelöli, amelyek korábbi ipari hasznosítása megszünt vagy nagyon visszaesett, és még nem ủjultak meg. Ezen övezet legföbb sajátosságai az elhagyott ipari területek és a lepusztult, régi ipari épületek (Barta 2004; BeluszkyGyöri 2004; Kukely et al. 2006). Akadnak azonban olyan nézetek is miszerint az összes ipari terület együttesen képezi a rozsdaövezetet. A különféle megközelítések között az elkülönítés alapját az adja, hogy az átmeneti (barna) zóna megnevezés elsősorban a városszerkezeti helyzetre, míg a rozsdaövezet elnevezés inkább az ipari területek állapotára, milyenségére utal. 
Tér és Társadalom 23. évf. 2009/2. 69-85. p.

Az értelmezéstől fưggően változik az övezetek nagysága is. A belváros és a külváros közötti átmeneti zóna a legnagyobb kiterjedésủ (Barta 2004; Beluszky-Györi 2004). A barnazóna területét, amely a tradicionális ipari területeket és a közéjük ékelődő egyéb (közlekedési, lakó-) funkciójú területeket is magában foglalja, 13\%-ra $\left(68 \mathrm{~km}^{2}\right)$ becsülték a föváros területébỏl (Kukely et al. 2006). A csak kizárólag ipari hasznosítású területek kiterjedése ennél jóval kisebbre tehető, elsősorban azért, mert már eredetileg is szerényebb mértékü volt a részesedésük, és részben azért is, mert csökkent a területük az elmúlt évtizedekben (Kiss 1994; 1999).

Az ipari területeken zajló változások térben és időben differenciáltan haladtak. A változás mértéke igen eltérỏ a város különbözỏ részeiben, de még egy ipari területen belül is, mivel az egyes ipari területek és az ott levő ipari létesítmények az átalakulás, a fejlödés más-más stádiumában vannak. Ez több tényezőre (pl. az ipari területek elhelyezkedése, az ottani üzemek nagysága, tulajdonosi struktúrája, szervezeti formája, ágazati hovatartozása) vezethető vissza. Lényegében ezek határozzák meg az adott ipari terület és az ottani ipari cégek további sorsát, jövőjét is. Az elmúlt évtizedekben voltak olyan ipari területek, amelyek szinte változatlanul fennmaradtak, legalább is külsejükben, és valószínủ egy részük a jövőben sem változik számottevően. Voltak olyanok is, amelyek kisebb-nagyobb mértékben megváltoztak, mert az ottani ipar megújult, átszerveződött, és ez az ipari épületek külsejében, az ipari területek hasznosításában, belső rendezettségének fokozódásában stb. is megnyilvánult. S akadtak olyanok is, nem is kevesen, amelyek teljesen eltüntek, és a helyüket más funkciók vették át, sőt új ipari területek is létrejöttek. Ezekhez hasonló folyamatokat a fejlett nagyvárosokban is megfigyeltek (Takeuchi 1985; Doling et al. 1994; Cohen 1998; Moulaert et al. 2003), habár azok mindegyikének megvannak a maguk egyedi, különleges vonásai is. A történelmi előzményektől, a gazdasági bázistól, a társadalmi, kulturális környezet milyenségétől stb. függően ugyanis mindenhol differenciáltan, bizonyos fokig sajátos módon következtek be ezek a változások (Ernst et al. 1996).

Budapest ipari területei az 1970-es évek elején érték el a legnagyobb kiterjedésüket, amikor a város területének több mint $9 \%$-át tették ki, s azután lassú fogyásuk kezdődött. Az 1980-as évek közepéig mintegy 250 hektárral csökkent a területük, ami többek között az ipari tevékenység korlátozásának, az ipar kitelepítéseknek és az iparban végbement változásokhoz való szorosabb igazodásnak tulajdonitható. Az 1990-es években tovább folytatódott, méghozzá egyre intenzívebben a tradicionális ipari területek zsugorodása, ám a város különböző részeiben eltérő mértékben. Voltak olyan városrészek, ahol az ipari területek fogyása a 30-40\%-ot vagy akár az 50\%-ot is elérte (Kiss 1999; 2002). Bár az utóbbi időben már általában véve mérsékeltebb az ipari területek csökkenése, mégis néhol még mindig tetemes fogyásuk figyelhető meg. Az elmúlt közel egy évtized változásait jól tükrözi az 1998. és 2006. évi felmérés tapasztalatainak az összevetése is. Ma már a főváros területének csak néhány százalékát teszik ki az átmeneti zóna tradicionális ipari területei (1. ábra). 
Tér és Társadalom 23. évf. 2009/2. 69-85. p.

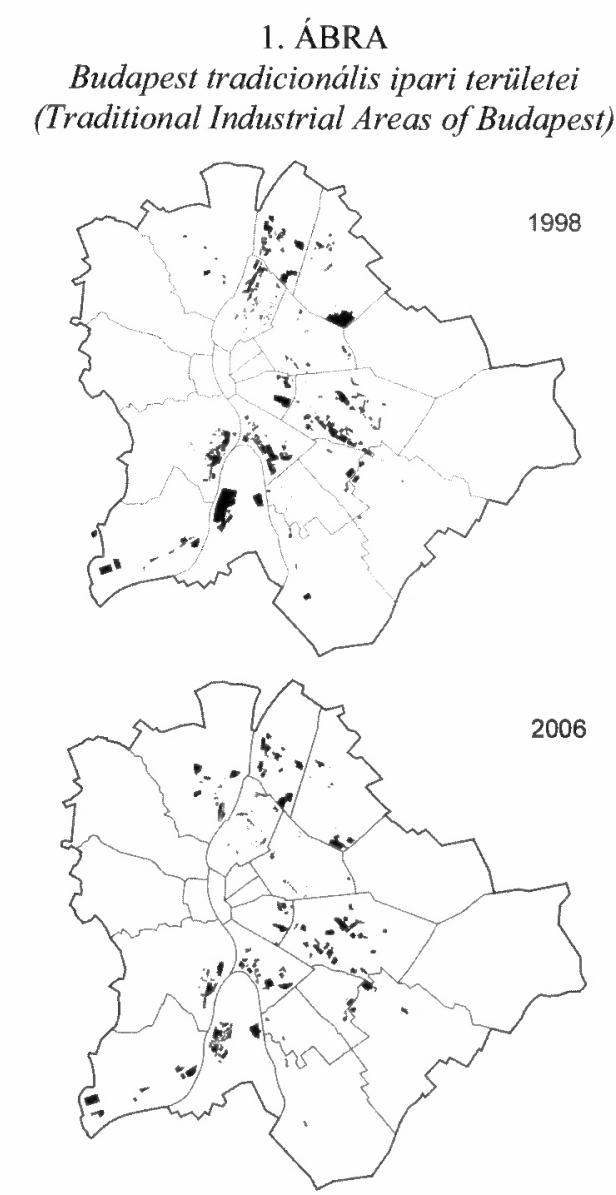

Forrás: Az 1998. évi és a 2006. évi felmérés és terepbejárás tapasztalatai alapján saját szerkesztés.

A hagyományos ipari területek nagyfokú összezsugorodása egyben azt a kérdést is felveti, hogy beszélhetünk-e még ipari körzetekről. A válaszunk erre határozott nem lehet, mivel azok mostanra már zömmel feldarabolódtak, „dezintegrálódtak”. Napjainkban már csak a foltokban, szórtan megmaradt régi ipari területek emlékeztetnek rájuk, és sejtetik az egykori előfordulásuk körvonalát. Természetesen arról sem szabad megfeledkezni, hogy ezek a fennmaradt, hagyományos ipari területek már nem ugyanazok, mint régen, hiszen az ott levő vállalkozások zöme hatalmas belső és részben külső átalakuláson ment keresztül 1989 után.

Az 1990-es évtizedben az ipari területek kiterjedését alapvetően két egymással párhuzamosan zajló folyamat határozta meg, amelyek változó intenzitással érvényesültek. Közülük az egyik a dezindusztrializáció, ami az ipari területek eltünésével, funkcionális átalakulásával járt, míg a másik, a rehabilitáció a régi ipari területek teljes vagy részleges megújulását és fennmaradását célozta. Az előbbi inkább a város 
északi, északkeleti ipari körzeteire volt jellemzö, ellenben az utóbbi jobbára a déli, délkeleti ipari területekre. De az is előfordulhatott, hogy a két folyamat egymás mellett levő ipari területeken vagy egy ipari területen belül zajlott. A két fö folyamaton kívül néhol még reindusztrializációval is számolni kellett. Bár ezek a folyamatok eltérő mértékben nyilvánultak meg a különböző ipari területeken, a fỏváros egészét, az összes ipari területet alapul véve a dezindusztrializáció volt a meghatározó folyamat.

A 2006. évi felmérés tükrében megállapítható, hogy a fỏváros iparában az 1998-ig tapasztalt folyamatok, bizonyos fokig ellentétes trendek az elmúlt közel egy évtizedben is folytatódtak. Továbbra is a dezindusztrializáció a domináns folyamat, habár mostanra már egyre jobban kiteljesedik a térben. Ez feltehetóen annak a következménye, hogy a városközponthoz közelebb lévő felesleges, úgymond „szabad” ipari területek már megfogyatkoztak, és az ilyen területek iránti növekvő igény miatt már a távolabb fekvő és/vagy rosszabb közlekedési kapcsolatokkal rendelkező ipari területek is elótérbe kerültek. Ezáltal a dezindusztrializáció még azokon az ipari területeken is jelentősebb lett a város északi (pl. IV. kerület) és föleg déli felében (pl. a XI. és XXI. kerületekben), ahol az 1990-es évtizedben kevésbé fordult elö. Mintha ezek a területek is igyekeznének „utolérni” a város északi részében elörehaladott funkcióváltást. Belejátszik ebbe a City további terjeszkedése is. Az utóbbi évtizedben már a városközponttól távolabbi területeken is megfigyelhető a „centrum funkciók” felbukkanása a központi üzleti negyed (CBD) „benyomulásának, csápszerü kiágazásának" köszönhetően.

Az 1990-es években a város északi felében, a XIII. kerületben haladt a leggyorsabban a dezindusztrializáció, ami az ezredforduló után északabbra „tolódott”, $\mathrm{s}$ az ottani ipari területeknek is releváns jellemzöjévé vált. Ennél fogva a hajdani ipari körzet napjainkra már szinte teljesen „felemésztödött” a város északi felében. A tradicionális ipari területek gyors zsugorodása annak is betudható (vagy esetleg annak is a következménye) a XIII. kerületben, hogy ugrásszerủen nőtt a megszủnt ipari cégek száma. (Például 1990 és 1995 között még csak 65 ipari cég szünt meg, 2000 és 2005 között viszont már 345.) Ma már csak apró foltokat alkotnak a kizárólagos ipari területek, a legnagyobb hányaduk ugyanis funkcióváltáson ment át (2. ábra).

A 21. század elején az ipar tartósabb fennmaradásával már csak a város keleti ipari területein, fơleg a X. kerületben lehet számolni, melynek hátterében a kerület városközponthoz viszonyított távoli fekvése, kedvezőtlenebb közlekedési kapcsolatai és iparának sajátos ágazati struktúrája állhat. Ezzel magyarázható, hogy a X. kerületben még a 2006-os felméréskor is igen tetemes volt az ipari területek aránya, ami egyben a dezindusztrializáció szerény mértékére is utal. Az ipar rehabilitációjával összefüggő beruházások leginkább a régi ipari létesítmények modernizálását, megújulását célozták, amelyek a „gyárkapun kívülállók” számára sokszor kevésbé látványosak (3. ábra). 


\section{2. ÁBRA}

Az iparterületek funkcionális átalakulása a föváros XIII. kerületében (Functional Transformation of Industrial Areas in the 13th District of Budapest)
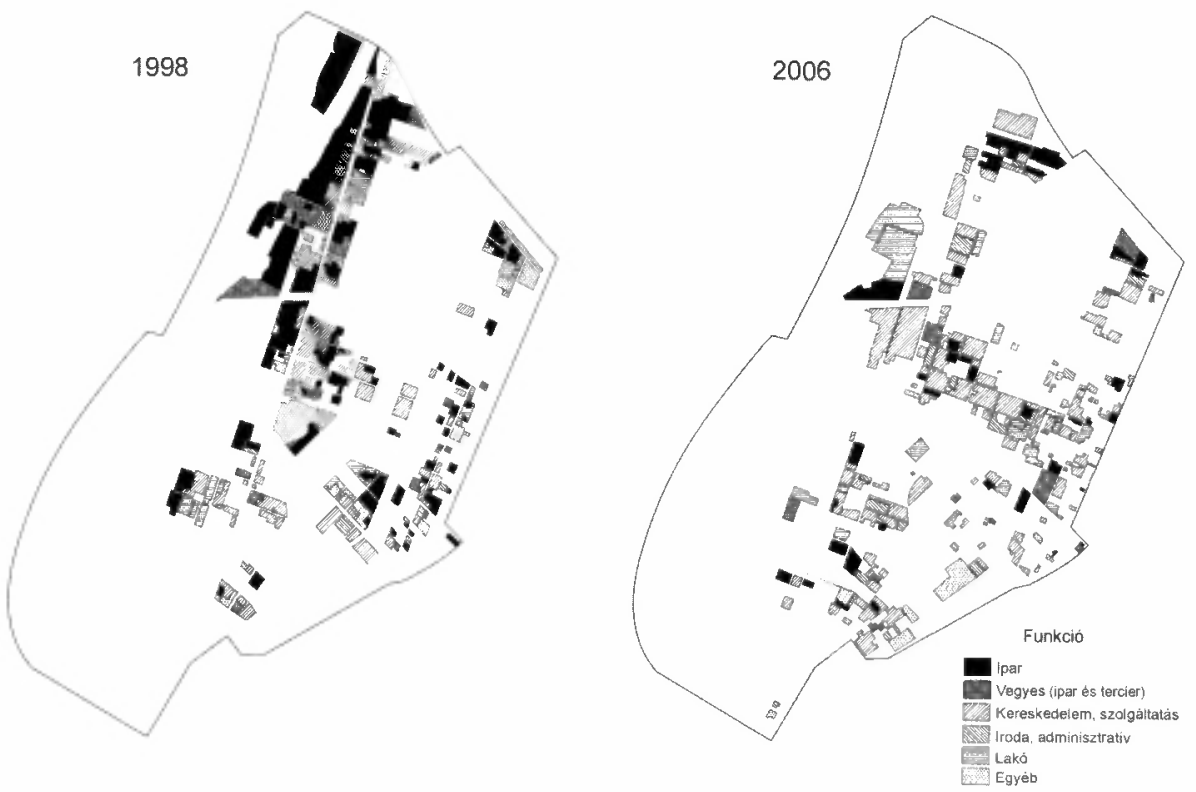

Megjegyzés: A XIII. kerület térképe, 2004.

Forrás: Az 1998-ban és 2006-ban végzett terepbejárás és felmérés tapasztalatai saját szerkesztés.

A dezindusztrializációval párhuzamosan reindusztrializáció is folyik. Jelzi ezt az ipari cégek számottevő szaporodása is. Ugyanakkor ellentmondani látszik a reindusztrializációnak az, hogy a tetemes számú (2000 és 2005 között közel hétezer) cégalapítás ellenére az ipari területek nem gyarapodtak nagymértékben. Oka lehet ennek az, hogy az új ipari területek aránya csekély, a régieké pedig fogy, ezért szinte úgy tủnik, mintha az új cégek zömének nem lenne területi vonzata, mintha nem is nagyon kapcsolódnának a fizikai térhez. Éppen emiatt az ipari területek nagyságára és az ipar térszerkezetére alig vannak hatással. Visszavezethető ez arra is, hogy az új ipari cégek között sok a kisvállalkozás, amelyek közül több régi ipari létesítményekben települt le, nem ritkán csak egy-egy helyiséget elfoglalva. Ennél fogva egységnyi ipari területre egyre több ipari cég jut, vagyis nö a cégsűrüség. Ezzel egyidejúleg a 2006. évi állapot-felmérés folytán az az egyelőre lassú és halványan körvonalazódó trend is kimutatható, hogy az ipari termelés súlypontja a város pereme felé tolódik el, a belső kerületekböl a külsők irányába (4. ábra). 
Tér és Társadalom 23. évf. 2009/2. 69-85. p.

Az utóbbi évtizedben a különbözö folyamatok eredőjeként tehát tovább csökkentek a tradicionális ipari területek, miáltal sok ilyen terület vált feleslegessé, „szabadon" felhasználhatóvá.

\section{3. ÁBRA}

Az ipari területek funkcionális átalakulása a föváros $X$. kerületében (Functional Transformation of Industrial Areas in the 10th District of Budapest)

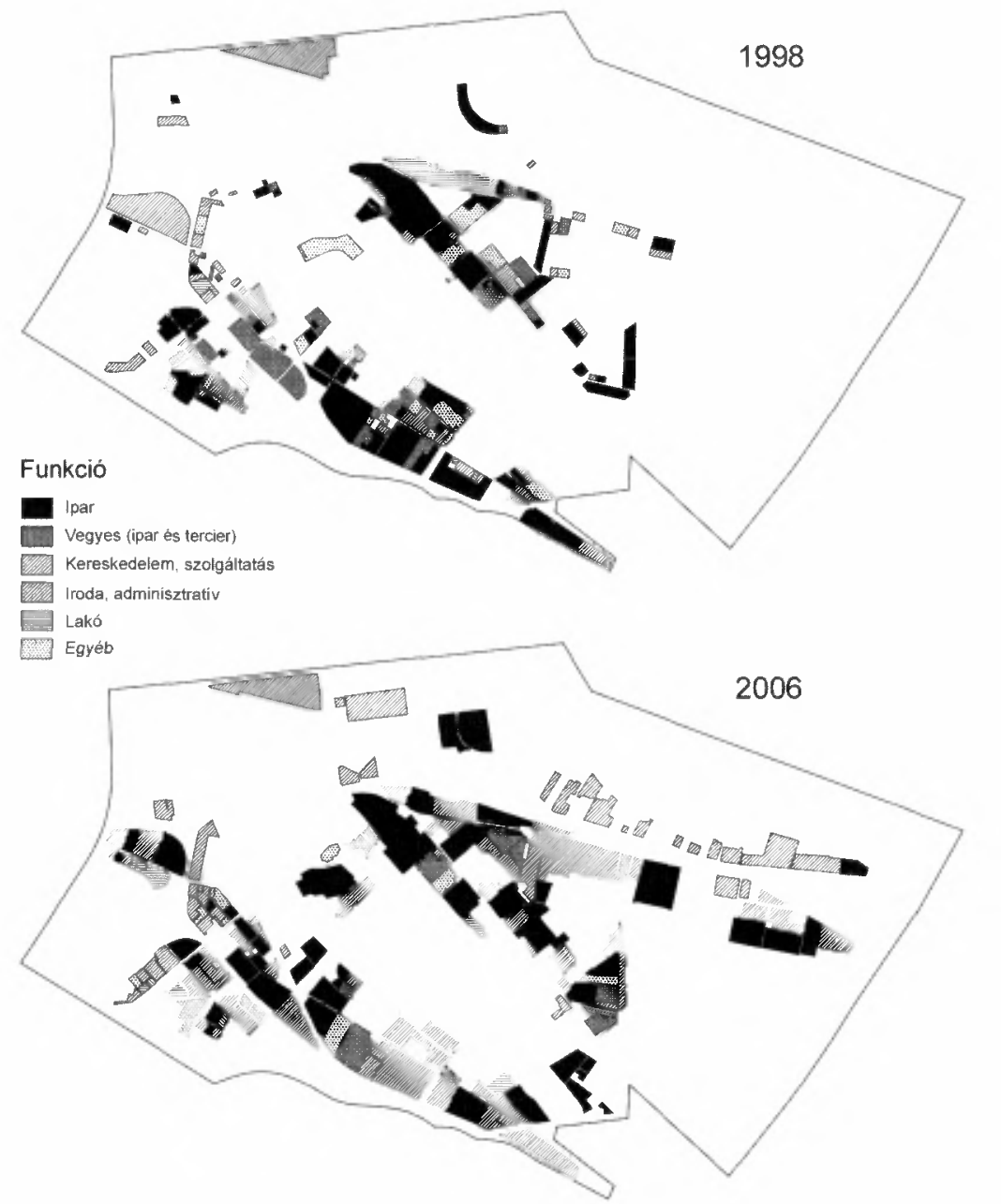

Megjegyzés: A X. kerïlet térképe, 2003.

Forrás: Az 1998-ban és 2006-ban végzett terepbejárás és felmérés tapasztalatai alapján saját szerkesztés. 


\section{4. ÁBRA}

Budapest ipari területei, 2006

(Industrial Areas of Budapest, 2006)

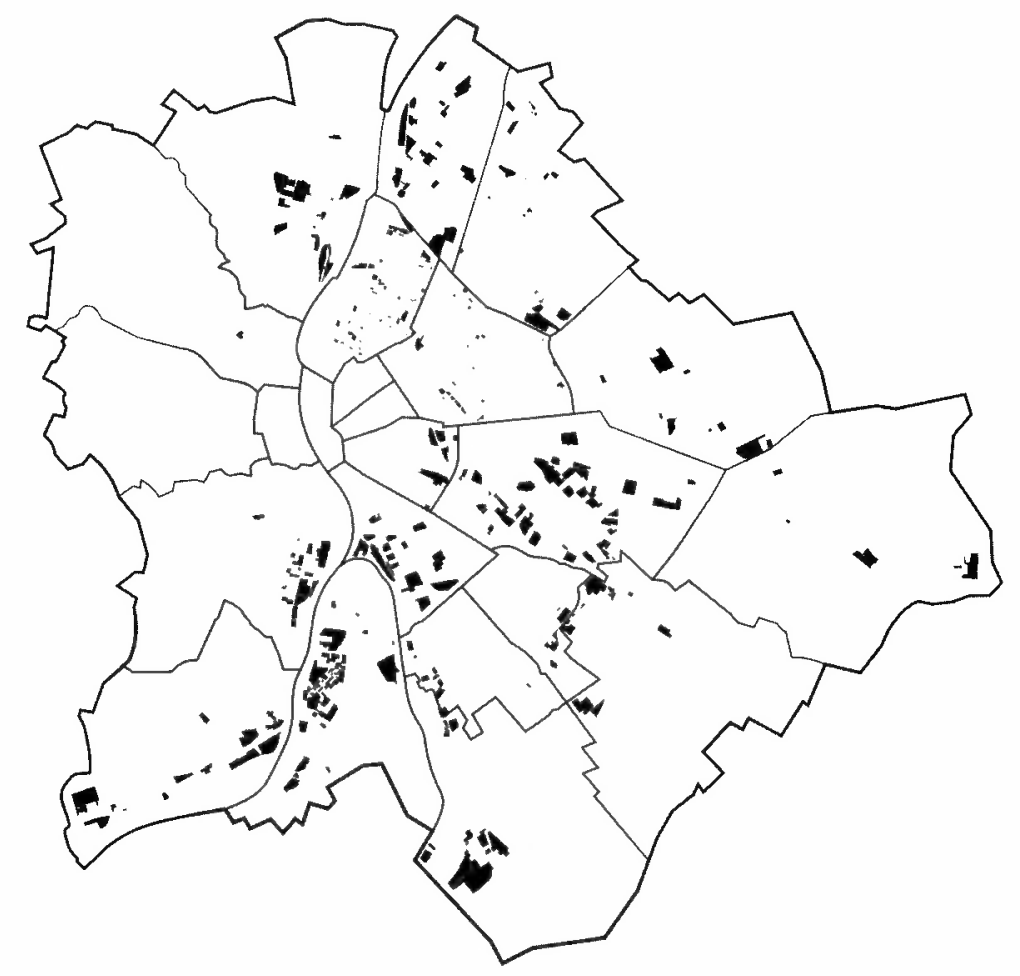

Forrás: A 2006. évi felmérés és terepbejárás tapasztalatai alapján saját szerkesztés.

\section{A tradicionális ipari területek újrahasznosítási típusai}

Az elhagyott ipari épületek és ipari területek újrahasznosításának módja több tényezőtől fưgg: például a nagyságuktól, elhelyezkedésüktől, tulajdonosaiktól, közlekedési kapcsolataiktól, szennyezettségük mértékétől, környezetük milyenségétöl, a városfejlesztési elképzelésektöl stb. Bár várostervezési, illetve városfejlesztési szempontból ezek a területek nagyon fontosak, mert funkcióváltásuk révén nagymértékben kihat(hat)nak a város jövőbeni szerkezeti és funkcionális tagolódására, mégis a helyi önkormányzatoknak, a városfejlesztőknek nagyon kevés eszközük van (pl. beépítési szabályok a magasságra vonatkozóan) a hasznosításuk befolyásolására. Kedvezőtlen továbbá az is, hogy a kerületek és a föváros között nincs mindig összhang egy-egy ipari terület jövőjét illetỏen. Nagyon nagy hátrány az is, hogy 
Tér és Társadalom 23. évf. 2009/2. 69-85. p.

hosszú időn (kb. tíz éven) át a fővárosnak nem volt városfejlesztési koncepciója. Következésképp a területhasznosítás spontán módon zajlott, melynek az lett az eredménye, hogy sok beruházás nem úgy és nem ott valósult meg, ahol és ahogyan kellett volna. Mivel ezek a területek általában magántulajdonban vannak, és a „magántulajdon szentsége" nagyon erős - ahogy az egyik fóépítész fogalmazott -, ezért a várostervezőknek kevés a tényleges befolyásuk. A döntő tényezők a piaci erők és az, hogy a tulajdonosoknak, a befektetöknek mi a szándéka az adott területtel.

A politikai rendszerváltozást követő „zürzavaros idökben” szinte minden nehézség nélkül, viszonylag olcsón meg lehetett szerezni ezeket az elhagyott, felesleges ipari területeket. Ez utóbbi azzal is magyarázható, hogy a közép- és kelet-európai fővárosok mindegyike majdnem egy időben „dobta piacra” ezeket a területeket, és a köztük levő versenyt kihasználták a külföldi befektetők. Könnyen és kevés pénzért juthattak jelentős ipari területekhez, amelyekkel most már szabadon rendelkeznek. A passzív városfejlesztés idöszakában maguk a befektetők, a tulajdonosok irányították a város fejlödését, mert ténylegesen ök döntöttek egy adott terület hasznositásáról (Szirmai et al. 2003). Csak az utóbbi években kezd határozottabban érvényesülni a korábbi passzív városfejlesztéssel szemben Budapesten is az aktív városfejlesztés (csakúgy, mint a nyugati nagyvárosokban), melynek lényege, hogy a helyi önkormányzatok nagyobb tudatossággal határozzák meg, hogy hol, milyen létesítmények legyenek, s azokhoz keresnek befektetőket, s nem fordítva.

Rendszerint azon felesleges ipari területek fejlesztése haladt gyorsabban, amelyek kedvezö(bb) földrajzi fekvéssel, jó közlekedési kapcsolatokkal rendelkeztek és nem voltak szennyezettek. A befektetők ugyanis ezeket a „tiszta” területeket részesítették előnyben, mert a szennyezések eltávolítása jelentősen megnövelte volna a költségeket. Nem beszélve arról, hogy sokkal időigényesebbé is tette volna a beruházást.

$\mathrm{Az}$ egykori ipari telephelyek újrahasznositása alapvetően kétféleképp történhet attól függően, hogy az új funkció a régi ipari létesítményben vagy azok lebontásával a régi ipari területen jelenik meg. Az elöbbi esetben a funkcióváltás a régi ipari épületekhez kapcsolódik, amelyeket többnyire valamilyen mértékben felújítottak, átalakítottak. Ekkor a belsỏ átalakulás külsőleg gyakran kevésbé látványos. Az ipari létesítmények ilyen, új kihívásokhoz való alkalmazkodását nevezte Cohen „adaptive reuse”nak, azaz alkalmazkodó újrahasznosításnak, mivel az épületek ,igazodnak" az új funkcióhoz (Cohen 1998). Az utóbbi esetben a régi ipari létesítmények teljes lebontása után az üres ipari területen egészen új, nem ipari tevékenységnek helyt adó épületeket hoznak létre, amelyek már külsejükben és tartalmukban, vagyis funkciójukban is teljesen újak. Ezek már a városképben is látványosabb változást eredményeznek, ezért ezt a típust városi megújulásnak (urban renewal) is nevezhetjük.

Mindkét típusnál az újrahasznosítás lehetséges módjai sok hasonlóságot mutatnak. E tekintetben nincs markáns különbség közöttük, bár vannak olyan módok, amelyek csak az egyik esetben lehetségesek ( $\mathrm{pl}$. a loft-lakások nem jöhetnek létre régi ipari épületek nélkül). Az is általános tapasztalat, hogy a kisebb méretú ipari területek, ipari épületek újrahasznosítása, funkcióváltása rendszerint gyorsabban halad, mint a nagyobbaké. 
Az ipari területek, létesítmények újrahasznosításának leggyakoribb módjai - fontossági sorrend nélkül - a kereskedelmi, szolgáltató, iroda, lakó-, és raktározásilogisztikai funkció. A vizsgálatok azt mutatták, hogy az egyes funkciók preferálásában időbeli eltolódás következett be. Az 1990-es években fớleg a kereskedelmi és a szolgáltató, valamint az iroda funkció dominált, a funkcióváltás elsősorban ezek irányába zajlott (Kiss 2002). Összefüggött ez a kereskedelem gyors privatizációjával, a nagy bevásárlóközpontok és modern irodaépületek hiányával is, amelyek iránt óriási volt a kereslet. A rendszerváltozás utáni nehéz helyzetből való kilábalás, a gazdaság stabilizálódása, a növekvő jövedelmek és a minőségi lakásigények fokozódása ösztönzöleg hatottak a lakásépítésekre is az ezredforduló táján. A raktározási, logisztikai funkciók csak az utóbbi években kezdtek egyre nagyobb szerepet kapni, ami talán abból is fakad, hogy a középtávú városfejlesztési koncepció elfogadásával nyilvánvalóvá váltak a fơ közlekedési útvonalak futásirányát követő fontosabb fejlesztések. Természetesen az egyes funkciók jelentősége a piaci igényektöl függően rövid időn belül is változhat. Mégis ezek tekinthetők, különösen a lakó- és a logisztikai funkció a legnépszerübbnek napjainkban. A befektetők a leginkább ezeket a beruházásokat támogatják.

A különbözö funkciók a térben is differenciáltan jelentek meg a hagyományos ipari területeken. A kereskedelmi, szolgáltató jellegü fejlesztések elsősorban ott valósultak meg, ahol jók voltak a közlekedési kapcsolatok. Az egyes beruházások nagysága igen eltérö, de általában tízezer négyzetméter alattiak, és a külső megjelenésükben is élesen különböznek ezek a modern, ,high-tech"-szerủ épületek. Szemben a nagyon nagy területigényủ kereskedelmi beruházásokkal, amelyek a városon kívül valósultak meg, és amelyek építészeti szempontból sem látványosak, mert túlnyomórészt igen egyszerủ szerkezetủ csarnokok.

A kereskedelmi, szolgáltató funkció egyaránt megjelenhet régi ipari épületben vagy hajdani gyárterületen. Az elöbbire az egyik legelsỏ példa a Váci úton levő Csavargyár épülete, amelybe felújítása, rekonstrukciója után számos, kisebb-nagyobb és döntően szerényebb igényeket kielégítö kereskedő és javító, szolgáltató cég költözött be. Az utóbbira a Duna Plaza a klasszikus példa, hiszen a fóvárosban először létesült barnamezős beruházás formájában régi ipari (hajógyári) területen egy ilyen modern, nyugati típusú bevásárlóközpont. 1996-ban került átadásra, ám azóta már jó néhány hasonló színvonalú épült. Ezekben az új típusú bevásárlóközpontokban általában sokféle, magasabb szintủ igényeket kielégítỏ üzletek és szolgáltató cégek kapnak helyet. A 21. század elejére a bevásárlóközpont-létesítés mérséklődött.

Az irodai, adminisztrativ jellegü fejlesztések az 1990-es években voltak gyakoriak, ami az 1989 után hirtelen jelentkező, rendkívül nagy igényeknek tudható be. Akkor az is elöfordult, hogy mindenféle felújitás vagy modernizálás nélkül használták a régi ipari épületeket irodai és adminisztratív funkcióra, mert eleinte a nagy volumenü mennyiségi igények kielégítésére törekvés dominált. A régi ipari épületek irodának alkalmas helyiségeinek a bérbeadása, mint a bevételszerzés sajátos módja, szintén hozzájárult a korábbi állami vállalatok fennmaradásához. Ez egyébként „túlélési stratégiájuknak" is egyik lehetséges eszköze volt. Később már a gazdasági körül- 
mények megváltozása és az irodák kínálatának növekedése következtében ez a fajta „azonnali hasznosítás" háttérbe szorult, amit az igényesebb, magasabb szintủ elvárásokat is kielégítő, korszerü, sok extrával ellátott irodák iránti kereslet erősödése is előidézett. A kezdeti nagy boom-ot követően a 21. század elejére az irodák iránti kereslet szintén visszaesett. 2002-ben még 15 iroda épült a barnaövezetben, részben gyárak helyén, de 2003-ban már csak néhány ilyen jellegú beruházást regisztráltak (Ongjert 2003). Ez elsődlegesen az irodapiac telítődésével, a kereslet csökkenésével magyarázható, habár jó minőségü irodákat még mindig sokan keresnek. Az irodaépületek között egyaránt megtalálhatók a régi ipari területen létrejött, teljesen új, modern irodaházak, mint barnamezős beruházások (pl. MOM Parki irodák) és a régi ipari épületek átalakításával, rehabilitálásával létrehozottak. Jó példa ez utóbbira a Dorottya udvar, amelyet a régi gyárépület teljes felújításával, rekonstrukciójával, de a tágas belső terek megtartásával „hoztak létre” a 2000 -es évek elején. Ez az épület az egyik legjobb példa a „loft-irodaházra” a fővárosban.

Többnyire az új, modern irodaházak a városközpontban, ezzel szemben a felújított ipari épületben levők a központtól távolabb helyezkednek el, amit némiképp ellensúlyoznak a jó közlekedési kapcsolatok, valamint a jól kiépített infrastruktúra. S mivel ez utóbbiak bérleti díjai rendszerint kisebbek, ezért sok kezdó vállalkozás kedveli ezen irodaházak helyiségeit.

A lakáscélú fejlesztés az ezredfordulótól került előtérbe. Hatalmas lakásépítési láz bontakozott ki az egykori ipari területeken. A legföképp azokon a régi ipari területeken, amelyek nem szennyezettek és jól megközelíthetök. Az ipari területek 1998-as felmérése során még azt tapasztaltuk, hogy a lakáscélú fejlesztés nem gyakori újrahasznosítási mód. A XIII. kerületben, a város egykori északi ipari körzetében voltak erre kísérletek az 1990-es években, de ezek a vállalkozások (akkor még) nem jártak sikerrel (Kiss 1999). A 21. század elejére viszont az elỏrehaladott dezindusztrializáció és a városrész funkcionális átalakulása következtében sokat változott a kerület és a róla alkotott kép. Részben ezzel magyarázható, hogy pl. 2005-ben már itt épült a legtöbb új lakás (3250) a fövárosban, ami messze a legmagasabb érték volt. Amig az 1990-es évtized második felében évente átlagosan 80 lakás épült a XIII. kerületben, addig 2000 és 2005 között már 1349 lakás. Szintén erösödött a lakásépítés üteme a város déli és keleti ipari területein. Például a IX. kerületben 1995-ben 88 lakást építettek, tíz évvel később már 1008-at, vagy például a XI. kerületben az 1990-es évek második felében átlagosan 214 lakás épült évente, a 2000-es évek elején pedig már 338. Az új lakások építésében magyar és küllföldi befektetök egyaránt részt vesznek. Az utóbbi években a német, angol, holland és osztrák befektetök mellett megnött a spanyol, az ír és az izraeli befektetők száma is. Az újonnan épített lakások általában jól felszereltek, több szobásak, gyakran lakóparkot alkotnak.

Az ún. „loft-lakások" Nyugat-Európában és Észak-Amerikában már jóval hamarabb megjelentek, mint Európa keleti felében (Cohen 1998). Jelenleg már a fövárosban is vannak példák arra, hogy a régi ipari épületeket alakítják át lakóházzá. Ezek a felújitott nagy területủ, nagy belmagasságú lakások kiválóan alkalmasak extrém igények (pl. lakó- és munkahelyi funkciók együttes) kielégítésére. Sok 
helyütt müvészek, zenészek, festők költöznek be ezekbe a lakásokba, amelyek többnyire a város déli, délkeleti ipari körzeteihez kapcsolódnak (Sütö et al. 2004). A ,loftlakások” gyakran „szigetszerüen” ékelödnek be a lakóterületekbe vagy közel vannak azokhoz annak ellenére, hogy ipari területeken helyezkednek el. 2006 nyarán már a fỏváros több helyén (pl. Óbudán a régi textilgyárban, Angyalföldön a volt gázkészülékgyárban, Ferencvárosban az egykori Gizella malomban) is terveztek loft-lakás kialakítást, illetve loft-lakásszerủ lakásépítést. Közülük a Gizella malom lesz az egyik legnagyobb beruházás, ahol 100 ilyen lakást szándékoznak felépíteni. Továbbra sem fog azonban a lakófunkció megjelenni azokon a régi ipari területeken, amelyek szennyezettek és/vagy a környezetük sem kedvezö.

A raktározási, logisztikai funkció megjelenése a régi ipari területeken az utóbbi években erősödött fel, s folyamatosan gyarapodik az így hasznosított ipari épületek aránya. Ezek a nagy helyigényü létesítmények föleg a városközponttól távolabb levő ipari területeken gyakoribbak, de csak ott, ahol jók a közlekedési kapcsolatok. Rendszerint a fố közlekedési útvonalak mentén helyezkednek el. A raktározási és a logisztikai piacon igen erös a spekulatív épités is, ami a fejlett országokban bevett épitési forma, nálunk csak nemrég jelent meg, és csak részben kapcsolhatók régi ipari területekhez (Szirmai et al. 2003).

A raktározási, logisztikai funkció nem ritkán nagyon lepusztult, régi gyárépületben is helyt kap, amit a terepbejárás során is megfigyelhettünk. Példaként a csepeli gyárterület említhető, ahol több épületen is a „raktár” vagy „raktár kiadó” feliratot olvashattuk. Ezek a „raktárépületek” eltérő nagyságúak voltak, s valószínủ rosszabb múszaki állapotukból fakadóan jóval olcsóbban bérelhetők, mint az új épitésủek és/vagy a fontosabb közlekedési folyosók mentén levők (5. ábra).

$\mathrm{Az}$ egyéb jellegü fejlesztések nem túl gyakoriak, és a régi ipari területeknek és/vagy épületeknek csak a töredékét teszik ki. Ide sorolhatók a parkolók, a parkok és az egyéb rekreációs területek, valamint a kulturális létesítmények. Ezek nagyon elvétve és igen kis területen fordulnak elő a fövárosban, $\mathrm{s}$ a jövőben sem várható jelentós gyarapodásuk.

$\mathrm{Az}$ „egyéb” kategóriával kapcsolatban még két megjegyzést kell tenni. Az egyik, hogy a raktározási, logisztikai funkció is ezen kategóriába került besorolásra a könnyebb kartografikus ábrázolás érdekében, hogy a kategóriák számának növelését elkerüljük. Ez viszont egyúttal azt is jelenti, hogy az egyéb kategóriába sorolt területek döntő hányada logisztikai, raktározási funkciót tölt be, s csak kismértékben ténylegesen is egyéb hasznositású ipari területet. A másik, hogy a 2006-os felmérés térképi megjelenitésekor szintén az elöbbi ok miatt szükségessé vált a fejlesztés elött álló, úgymond üres ipari területek ezen csoportba való besorolása is, mivel ezek további hasznosítása nem volt ismert a felmérés időpontjában. Ugyanez mondható el azokról a területekröl, amelyeken még a bezárt gyárak lepusztult épületei álltak, mert ezek további sorsa, ismeretlennek, bizonytalannak tünt akkor. Az azonban biztos, hogy ezen területek kiterjedése sem öltött tekintélyes méreteket, vagyis az „egyéb” területek kis részét tették csak ki 2006-ban. 
Tér és Társadalom 23. évf. 2009/2. 69-85. p.

\section{5. ÁBRA}

A föváros XXI. kerületének ipari területei funkció szerint, 2006

(Industrial Areas by Function in the 21st District of Budapest, 2006)

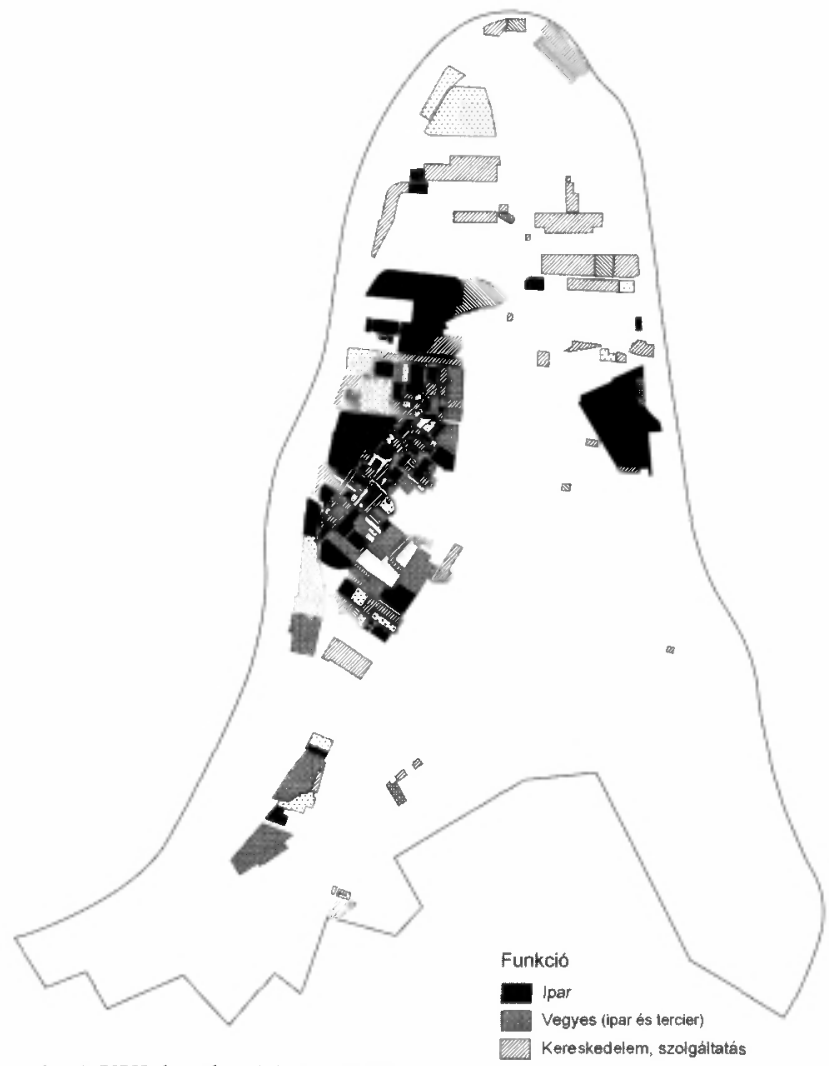

Megjegyzés: A XXI. kerület térképe, 2004.

Forrás: A 2006. évi felmérés és terepbejárás tapasztalatai alapján saját szerkesztés.

A felmérések tapasztalatai azt mutatták, hogy az ipari területek zöménél közvetlen funkcióváltás ment végbe, például az ipar helyébe ,azonnal” kereskedelmi vagy adminisztrativ funkció települt. De az is elöfordult, hogy közvetett volt a funkcióváltás, mert többféle tevékenység követte egymást, mielőtt a „végleges" funkció megjelent. Például az ipari funkciót először a kereskedelmi vagy raktározási funkció váltotta fel, melyet azután a lakófunkció követett. Úgy túnik tehát, hogy az ipari területek döntő hányada sajátos fejlödést, ,életutat” járt be.

Manapság már az is egyre gyakoribb, hogy egy régi ipari területet többféle funkcióra használnak, azaz terjed a komplex hasznosítás. A XII. kerületi MOM Park kitủnő példa erre. A régi gyárterület helyén egyszerre és egymás mellett került kialakításra a lakó-, a kereskedelmi-szolgáltató és az adminisztratív, irodai funkció.

A funkcióváltás folytán mostanra már a fơváros régi ipari területeinek tekintélyes hányadát a kereskedelmi és a szolgáltató funkciók foglalják el, de gyors ütemben 
növekszenek a lakó- és a raktározási, logisztikai funkciójú területek is. A funkcionális átalakulásnak a leglátványosabb példája a XIII. kerület, ahol jó másfél évtized alatt a hajdani ipari negyedböl üzleti negyed jött létre. Kerületi szinten eddig itt következtek be a legnagyobb mértékú változások, és még jelenleg is hatalmas fejlesztések színtere (pl. a Duna-part revitalizálása). A funkcióváltás miatt a homogén ipari területek egyre heterogénebbek lettek a föváros más ipari körzeteiben is, de a föbb ipari körzetek közül a keletiben volt a legszerényebb ez a folyamat.

\section{Összefoglalás}

Az 1990-es évek végén megjelent tanulmány összefoglalójában írt megállapítások túlnyomórészt ma is érvényesek, azzal a kitétellel, hogy az akkor jelzett folyamatok mostanra már jóval előrehaladottabbak lettek. Nevezetesen: tovább zsugorodtak a tradicionális ipari területek, a funkcióváltás kiteljesedett és újabb funkciók kerültek elötérbe, továbbá a város szerkezeti és funkcionális megújulása még szembetünőbbé vált. A második munkahelyi övezet mostanra már eröteljesen átalakult. Az ipari funkció helyét sok helyütt a multifunkciós munkahelyi terület vette át. A funkcióváltás ma még egyáltalán nem tekinthető lezárt folyamatnak. Tulajdonképpen egy „ủj város" születésének lehetünk a szemtanúi, melynek iparával még hosszú távon, ám hagyományos ipari területeivel már egyre kevésbé számolhatunk a jövöben. Mindezek együttesen nemcsak az ott élök fizikai környezetét, a városi életteret, hanem az ott lakók összetételét, a helyi társadalom milyenségét is egyre mélyebben formálják át.

\section{Jegyzet}

${ }^{1}$ A felmérés a T046014 sz. projekt keretében az OTKA támogatásával valósult meg, amelyért ezúton is köszönetünket fejezzük ki.

\section{Irodalom}

Barta Gy. (2002) A magyar ipar területi folyamatai két gazdasági rendszerben, 1945-töl 2000-ig. Dialóg Campus Kiadó, Pécs.

Barta Gy. (szerk.) (2004) A budapesti barnaövezet megújulási esélyei. MTA Társadalomkutató Központ, Budapest.

Beluszky P.-Győri R. (2004) A budapesti barnaövezet határai. - Barta Gy. (szerk.) A budapesti barnaövezet megújulási esélyei. MTA Társadalomkutató Központ, Budapest. 71-79. o.

Berényi I. (1994) Budapest városszerkezetének átalakulási tendenciái. - Földrajzi Értesitó. $3-4$. 221-233. o.

Coffey, W.-Bailly, A. (1996) Economic Restructuring: A conceptual framework. - Lever, W.-Bailly, A. (eds.) The spatial impact of economic changes in Europe. Ashgate Publishing Ltd., Hants. 13-40. o.

Cohen, P. (1998) A transforming San Francisco industrial landscape. - Pacifica. Fall. 7-12. o.

Csanádi G.-Ladányi J. (1992) Budapest térbeni-társadalmi szerkezetének változásai. Akadémiai Kiadó, Budapest.

Doling, J.-Koskiaho, B.-Virkkala, S. (eds.) (1994) Restructuring in old industrial towns in Finland. University of Tampere, Tampere. 
Kiss Éva : Budapest ipari területei az utóbbi évtizedben.

Tér és Társadalom 23. évf. 2009/2. 69-85. p.

TÉT XXIII. évf. 2009 — 2

Budapest ipari területei ...

Ernst, M.-Alexeev, M.-Marere, P. (1996) Transforming the core. Restructuring industrial enterprises in Russia and Central Europe. Westview Press, Boulder-Oxford.

Kiss É. (1994) Az ipari struktúra átalakulásának városszerkezeti konzekvenciái. - Földrajzi Értesitö. 3-4. 251-257. o.

Kiss É. (1999) Térszerkezeti és funkcionális változások Budapest ipari területein 1989 után. - Tér és Társadalom. 4. 119-135. o.

Kiss É. (2002) A magyar ipar térszerkezeti változásai. - Földrajzi Értesitő. 3-4. 347-365. o.

Kiss É. (2007) Traditional industrial areas of large cities in the post-socialist era, the case of Budapest and Warsaw. - Kovács, A. (ed.) Regionality and/or Locality. CRS HAS, Pécs. 143-156. o.

Kukely Gy.-Barta Gy.-Beluszky P.-Györi R. (2006) Barnamezós területek rehabilitációja Budapesten. Tér és Társadalom. 1.57-71.o.

Mendöl T. (1963) Általános településfóldrajz. Akadémiai Kiadó, Budapest.

Moulaert, F.-Rodriguez, A.-Swyngedouw, E. (eds.) (2003) The globalized city. Economic restructuring and social polarization in European cities. Oxford University Press, Oxford.

Ongjert R. (2003) Javaslat Budapest rozsdaövezeteinek rehabilitációs koncepciójára. Döntéselókészitö tanulmány, vitaanyag. Studio Metropolitana, Budapest.

Prinz Gy. (1964) A Budapesti Régió problémái. - Preisich G. (szerk.) Budapest városrendezési problémái. Kézirat. Budapest. 26-74, o.

Sütó A.B.-Soóki-Tóth G.-Valkó D. (2004) „Loftprogram" - a budapesti barnazóna reurbanizálásának esélyei. - Barta Gy. (szerk.) A budapesti barnaövezet megújulási esélyei. MTA Társadalomkutató Központ, Budapest. 245-257. o.

Szirmai V.-Baráth G.-Bognár J. (2003) Globalizáció és városfejlödés Budapesten. - Társadalomkutatás. 3. 249-274. o.

Takeuchi, A. (1985) Change of land use and industrial community in Tokyo. - Sinchini New Geography. 4. 33-45. 0 .

\section{INDUSTRIAL AREAS OF BUDAPEST IN THE LAST DECADE}

\section{ÉVA KISS}

After 1989 radical changes have started in the industry of Budapest, which have had a great impact directly or indirectly on the location of industry and on the utilization of former industrial areas. The main purpose of this study is to demonstrate the major processes and changes on the traditional industrial areas taken place in the last decade. Namely, how large these old industrial areas are and how they are reutilised. The study is based upon the results of a survey carried out in 2006 to reveal the measure of the functional transformation of industrial areas.

During the last decade the former processes (deindustrialisation, rehabilitation, decrease of industrial areas, change in their function) have been continued, but to a different degree. Due to them the spatial pattern of the city and its functional division have significantly transformed by now. 